ISA

Arboriculture \& Urban Forestry 2017. 43(1):38-46

\title{
Fine Root Growth Response to Soil-Applied Nitrogen and Paclobutrazol
}

\author{
Gary Watson and Angela Hewitt
}

\begin{abstract}
Practices to promote tree root growth have been sought in arboriculture for many years, especially as a treatment for trees that are stressed or in decline. Tree fertilization is a common practice in arboriculture. A few research reports have shown that nitrogen fertilization can increase fine-root density in localized areas of soil where the fertilizer has been applied, but the effect on the whole root system has not been investigated. Research has reported fine-root stimulating effects from basal application of the growth regulator paclobutrazol, but results have not been consistent. More information is needed. A slow-release granular formulation of nitrogen was broadcast over the entire root system of mature oaks for four consecutive years, with or without a paclobutrazol basal drench in the first year. Nitrogen was also applied to younger green ash and black maple as granular broadcast or subsoil liquid soil injection for two consecutive years. There was no overall increase in fine-root development from any of the treatments, and no localized increase from soil injection application of nitrogen. Growth response of the crowns was minimal. Soil profiles were undisturbed with moderate natural nitrogen availability. The results suggest that routine fertilization of trees at standard recommended rates may be ineffective if soil fertility is moderate.

Key Words. ANSI A300 Standard for Tree Care Operations; Fertilization; Growth Regulator; Injection; Nitrogen; Paclobutrazol; Root Growth; Root Stimulation.
\end{abstract}

Nutrient deficiency symptoms are not frequently observed on most species of trees growing in urban and suburban landscape situations, yet routine tree fertilization is commonly offered by arborists. Rather, fertilization should be based on demonstrated need and specific objectives (e.g., deficiency symptom, soil or foliar analysis, clearly defined growth objective) (ANSI 2011; Smiley et al. 2013). One objective of fertilization, listed in the current ANSI A300 Standard for Tree Care Operations (Part 2), is to enhance root function and development (ANSI 2011), but existing research to support this objective is limited.

While there can be little argument against application of nutrients to overcome a deficiency, nitrogen is the primary nutrient recommended by arborists for routine maintenance fertilization. Routine fertilization is often justified on the basis that it is a substitute for natural nutrient cycling that is disrupted by the removal of fallen leaves and twigs in landscapes (Smiley et al. 2013). Current recommended nitrogen fer- tilization rates are not consistent with natural nutrient recycling. In an eastern deciduous hardwood forest, the amount of nitrogen in fallen litter was measured at $0.27-0.46 \mathrm{~kg} \mathrm{~N} / 100 \mathrm{~m}^{2} /$ yr (Wells et al. 1972; Larcher 1975). The amount of nitrogen potentially returned to the soil from tree litter of four landscape tree species was similar, or slightly higher, at $0.48-0.72 \mathrm{~kg} \mathrm{~N} / 100 \mathrm{~m}^{2} /$ yr (Werner 2000). The recommended annual rates for landscape tree fertilization of $0.96-2.88$ $\mathrm{kg} \mathrm{N} / 100 \mathrm{~m}^{2} / \mathrm{yr}$ are up to 10.6 times greater than the amount that would be lost through litter removal (ANSI 2011; Smiley et al. 2013).

In addition to direct tree fertilization, nitrogen fertilization of lawns around trees in urban landscapes may also exceed rates of replenishment of nutrients lost by removal of litter. Annual fertilization program recommendations for cool- and warm-season turfgrass varieties are $0.96-2.50 \mathrm{~kg} \mathrm{~N} / 100 \mathrm{~m}^{2} / \mathrm{yr}$ (Landschoot 2003; Bigelow et al. 2013; Sartain 2015). In a survey of lawn care practices, homeowners 
reported actual annual application of 0.24-1.51 $\mathrm{kg} \mathrm{N} / 100 \mathrm{~m}^{2} / \mathrm{yr}$ (Osmond and Hardy 2004).

Fertilization may not be able to improve overall root system development unless low soil nutrient levels are limiting root growth (Philipson and Coutts 1977; Yeager and Wright 1981). Nitrogen application in localized areas of soil can increase fine-root density where the nutrient has been applied (Drew and Saker 1975; Chamuah 1988, Robinson 1994; Watson 1994; Hodge 2004). Although production of fine roots can be increased locally where nutrients are applied, there may be an overall reduction in the root:shoot ratio (Philipson and Coutts 1977; Yeager and Wright 1981; Mackie-Dawson et al. 1995; $\mathrm{Qu}$ et al. 2003; Rytter et al. 2003). The reduction in root:shoot ratio may result in a larger crown than can be supported by the root system (Watson 1991).

Tree age and size must also be considered when determining nitrogen fertilizer rates. On younger trees with adequate space to expand above and below ground, the goal of rapid growth may be valid. Smiley et al. (2013) recommend $0.1 .44-2.88 \mathrm{~kg} \mathrm{~N} / 100 \mathrm{~m}^{2} / \mathrm{yr}$ for trees that have not yet reached their mature size, if rapid growth is the primary objective. This is consistent with rates of nitrogen fertilization reported for field production of woody plants, typically $1.3-2.8 \mathrm{~kg}$ $\mathrm{N} / 100 \mathrm{~m}^{2} / \mathrm{yr}$ (Cripps 1992; Ingram et al. 1998; Juntunen and Rikala 2001; Cregg et al. 2004).

For older trees, maintenance of moderate vigor and growth rates, and a favorable root-crown balance are desirable. For mature trees, best management practices (Smiley et al. 2013) recommend maintenance rates of $0.96-1.44 \mathrm{~kg} \mathrm{~N} / 100 \mathrm{~m}^{2}$, but allow up to a maximum rate of $2.88 \mathrm{~kg} \mathrm{~N} / 100 \mathrm{~m}^{2}$. The higher rate is very similar to the rate used to promote rapid growth of nursery stock. Even the lowest rate exceeds the amount of nutrients lost through litter removal and may not be appropriate for mature trees when rapid growth is not the goal.

Arborists often contend that applications of lawn fertilizer are ineffective for trees (Lanphear 2000; ANSI 2011; Smiley et al. 2013), presumably because the nutrients are utilized by turf before reaching the underlying tree roots. While tree root densities can be reduced in the uppermost soil layers where competition with grass roots is most intense, they are not completely eliminated (Watson 1988; Green and Watson 1989). Shade from trees can also weaken the turfgrass beneath it, reducing root competition from the grass. Lawn grasses do not absorb all of the fertilizer applied to them. The amount of nitrogen leached can vary widely from less than $1 \%$ to $71 \%$ of that applied (Petrovic 1990; Guillard and Kopp 2004; Barton and Colmer 2005; Paré et al. 2006; Mangiafico and Guillard 2007). The amount of nitrogen leached through the soil profile was similar in a forest and unfertilized lawn system at $1.4 \mathrm{~kg} / \mathrm{ha}$, compared to $6.0 \mathrm{~kg} / \mathrm{ha}$ in fertilized lawns (Gold et al. 1990). This evidence suggests that nitrogen applied to lawns is available to tree roots even if their development near the surface is somewhat limited by turfgrass competition.

In part, because of this concern over surfaceapplied nutrients to lawns not reaching tree roots, subsurface soil injection application is often preferred by arborists. Studies have reported no difference between broadcast application, drill holes filled with granules, and liquid injection applications (Neely et al. 1970; Funk 2000), or only a slightly greater growth response from holes filled with granules (Smith 2000).

The gibberellin-inhibiting tree growth regulator paclobutrazol (PBZ) has been shown to increase root growth of trees in certain landscape situations (Watson 1996; Watson 2004; Watson and Himelick 2004). Little is known about the interaction with nitrogen fertilization.

The objective of this study was to investigate whole root system response of both young and mature trees to application of slow-release $\mathrm{N}$ at recommended rates, by liquid soil injection or broadcast application, alone or in combination with PBZ. The effect on crown characteristics was also assessed to capture the overall effect on tree growth and vigor resulting directly from the fertilization treatments, indirectly from potential root system enhancement.

\section{METHODS}

Two separate field studies were conducted to test the validity of routine $\mathrm{N}$ application to enhance root development. Young, rapidly growing ash (Fraxinus spp.) and maple (Acer spp.), species commonly planted in urban landscapes, were used to test fertilizer rates and application methods. The second study tested fertilizer rates 
and PBZ application on mature, native oaks. Turfgrass was present around the trees on both sites. Total soil nitrogen in the upper $15 \mathrm{~cm}$ of soil before application of nitrogen fertilizer was $0.21 \%$ on both sites, in the middle third of the normal range of $0.06 \%-0.5 \%$ (Bremner 1965).

\section{Mature Oak Experiment}

Thirty-six mature bur oaks (Quercus macrocarpa), and 18 mature white oaks (Quercus alba), growing among a larger group of trees with overlapping root systems were used. The trees were aging, but healthy and showing no major signs of decline. The study trees averaged $66.0 \mathrm{~cm}$ dbh. No fertilization or maintenance other than mowing was performed for many years previous to the initiation of the fertilization study.

The soil was an undisturbed, somewhat poorly drained Nappanee silt loam (NRCS 2016). Soil tests showed low phosphorous levels in the soil in both fertilized and control trees. Triple super phosphate (0-45-0) was applied at $0.96 \mathrm{~kg} \mathrm{~N} / 100$ $\mathrm{m}^{2} /$ year, during the first three years until levels increased to normal range. Soil organic matter was $4 \%-6 \%$ in the upper $15 \mathrm{~cm}$ of topsoil.

The crowns of the trees formed a forest-like closed canopy and the root systems likely overlapped somewhat. To avoid exposing a portion of a tree's root system to another treatment, fertilizer treatments were applied to trees in groups. Treatment areas were based on $12 \mathrm{~cm}$ radius $/ \mathrm{cm} \mathrm{dbh}$. The overlap of portions of the root system adjacent to other trees in the group would result in a smaller "shared dose" of fertilizer, but would likely be balanced by a smaller crown, also resulting from the closer spacing.

PBZ (Cambistat 2SC, Rainbow Treecare Scientific Advancements, Minnetonka, Minnesota, U.S.) was applied once at the beginning of the study and according to the label instructions (rate of $1.2 \mathrm{~g}$ a.i. $/ \mathrm{cm}$ dbh for oaks) as a basal drench in a shallow furrow around the base of the tree. Granular 38-0-0 fertilizer (Nu-Gro Nitroform ${ }^{\circledast}$ ), composed of a urea formaldehyde nitrogen source with $71 \%$ of the nitrogen from a water-insoluble fraction, was applied annually for four years on fertilized trees. Application rates were $0,0.96$, or $2.88 \mathrm{~kg} \mathrm{~N} / 100 \mathrm{~m}^{2}$, the lower and upper limits of the standard recommended range (ANSI 2011). The lower-rate treatment was applied in May of each year. The higher-rate treatment was applied half in May and half in August.

Twig growth and leaf area were measured in August each year. An aerial lift was used to remove three twig samples per tree from the upper half of the crown, equally spaced from around the crown. The distance from the bud scale scars to terminal bud tip was recorded in $\mathrm{cm}$. The area of the first three fully-expanded leaves was measured on a Delta-T Area Meter (Delta-T Devices, Burwell, Cambridge, England).

Relative chlorophyll content was measured on each of the leaves used for leaf area with a Minolta SPAD-502 meter. Five measurements were taken on different lobes of each leaf and averaged.

Foliar $\mathrm{N}$ was determined using the Dumas method (AOAC 2012) on an Elementar Rapid $\mathrm{N}$ analyzer (A\&L Great Lakes Laboratories, Ft. Wayne, Indiana, U.S.). Determination of total soil nitrogen in the soils was by way of the Kjeldahl method (Bremner 1965). Soil samples were collected with a $19 \mathrm{~mm}$ diameter soil sampler and cores were divided into $0-15 \mathrm{~cm}$ and $15-30 \mathrm{~cm} \mathrm{sec-}$ tions for processing. Two cores were taken around each tree and the cores were combined into the same groups by which the fertilizer was applied.

Fine-root development was measured near the end of the fourth season of fertilization using root density cores. One $42 \mathrm{~cm}$ deep, $7 \mathrm{~cm}$ diameter core was taken $1.5 \mathrm{~m}$ from the base of each tree. Cores were stored at $4^{\circ} \mathrm{C}$ until processing. Soil was washed from the roots, and oak roots were separated from other roots and debris by hand. Length of fine roots $(<2 \mathrm{~mm}$ diameter) was measured and converted to fine-root density with a WinRhizo system (Regent Instruments, Quebec, Canada).

One-way ANOVA $(P \leq 0.05$, Normality, $P>0.05)$ with separation of means by the Holm-Sidak Method (SigmaStat 3.0, SPSS Science) was used to compare fine-root density, $\mathrm{dbh}$ increase, twig growth, leaf area, leaf $\mathrm{N}$, and SPAD measurements from each year.

\section{Young Tree Experiment}

A existing plot of trees at The Morton Arboretum, Lisle, Illinois, U.S., growing at $4.8 \mathrm{~m}$ spacing on an Ozaukee silt loam soil (NRCS 2016) was utilized. Trees exhibited typical growth and color for their species and age. The turf 
was mowed only two or three times each growing season and clippings were not collected. No supplemental irrigation was provided.

Thirty 'Summit' green ash (Fraxinus pennsylvanica 'Summit'), $14.8 \mathrm{~cm}$ average caliper and 12 'Green Column' black maples (Acer nigrum 'Green Column'), $15.6 \mathrm{~cm}$ average caliper, likely grafted on sugar maple (Acer saccharum) root stock, but not confirmed, were selected from a larger group. Ash were fertilized by liquid soil injection and broadcast applications (15 trees each). Maples were fertilized by liquid soil injection application only due to the limited number of trees available.

In order to measure whole root system response, root systems were isolated by trenching at the midpoint between trees $(2.4 \mathrm{~m}$ from each tree) and placing plywood barriers into the trench before backfilling. This midpoint was typically less than $30 \mathrm{~cm}$ beyond the drip line. The trenches cut very few tree roots over $6 \mathrm{~mm}$ diameter, so the total root system of each tree was not substantially disturbed or reduced by the trenching.

$\mathrm{Nu}-\mathrm{Gro}$ Nitroform fertilizer (38-0-0) was applied in granular form for broadcast application, and the powder form dissolved in water for subsurface injection application. Both are a urea formaldehyde nitrogen source, with $71 \%$ of the nitrogen from a water-insoluble fraction. Nitrogen was applied for two consecutive years at 0.96 or $2.88 \mathrm{~kg} \mathrm{~N} / 100 \mathrm{~m}^{2}$, the lower and upper limits of the standard recommended range (ANSI 2011). For broadcast applications, the granular fertilizer was spread evenly over the entire isolated root system in the first week of June. Liquid injections were arranged in a $2.4 \mathrm{~m}$ square pattern, locating the holes halfway between the trunk and the root barrier. For the liquid injections, the fertilizer powder was dissolved in the same amount of water $(94.6 \mathrm{~L} /$ tree $)$ for both rates and distributed equally among injection points $(2.6 \mathrm{~L}$ at each) approximately $30 \mathrm{~cm}$ apart, $15 \mathrm{~cm}$ deep. In the first year, the liquid fertilizer application was delayed until late June and applied in two smaller applications because of wet soil conditions. The second year, drier soil conditions allowed all of the fertilizer to be applied in a single application at the same time as the broadcast application.

Two terminal twig samples per tree were pruned from halfway up the crown on opposite sides. No samples were taken the same year as the first $\mathrm{N}$ application since the $\mathrm{N}$ fertilizer was applied after growth for the year was essentially complete. Samples were collected in September of the second year, capturing growth from the first season after the initial $\mathrm{N}$ application, and again the following June after terminal buds had set. The final harvest was destructive, and 10 samples per tree were collected. The distance from the bud scale scars to the terminal bud tip was recorded on each terminal twig sample. The area of three fully expanded leaves per twig sample was measured on a Delta-T (video) Area Meter (Delta-T Devices, Burwell, Cambridge, England).

Relative chlorophyll content was measured twice on each of the leaves used for leaf area measurements with a Minolta SPAD-502 meter.

Fine-root development was measured using root density cores in June of the second year, a few days after the tops were harvested. One $30 \mathrm{~cm}$ deep, 7 $\mathrm{cm}$ diameter core was taken $0.6,1.2$ (soil injection location), and $1.8 \mathrm{~cm}$ from the trunk in east and west directions. Cores were stored at $4^{\circ} \mathrm{C}$ until processed. Soil was washed from the roots, and ash and maple roots were separated from other roots and debris by hand. Length of fine roots $(<2 \mathrm{~mm}$ diameter) was measured and converted to fineroot density with a WinRHIZO ${ }^{\mathrm{m}}$ image analysis system (Regent Instruments, Quebec, Canada).

One-way ANOVA $(P \leq 0.05$, Normality, $P>0.05)$, with separation of means by the Holm-Sidak Method (SigmaStat 3.0, SPSS Science), was used to compare fine-root density, caliper increase, twig growth, leaf area, and SPAD measurements from each year.

\section{RESULTS \& DISCUSSION}

\section{Mature Oak Experiment}

Neither the broadcast $\mathrm{N}$ fertilization nor basal drench PBZ treatments, separately or combined, affected fine-root density of mature oaks growing with turfgrass competition in the root zone (Figure 1, white oak data not shown). The vertical distribution was similar to other species in a similar soil type (Watson 2006a; Watson and Kelsey 2006), with maximum fine-root development within $10 \mathrm{~cm}$ of soil surface, diminishing rapidly between 10 and $20 \mathrm{~cm}$, and lower throughout the remainder of the soil profile. Turfgrass competition and/or more extreme fluctu- 
ation of soil conditions (moisture, temperature, etc.) near the surface may have been responsible for the lower tree root density in the uppermost $3 \mathrm{~cm}$ of soil.

Fertilizer and PBZ treatments had little or no significant effect on twig and leaf growth. PBZ is a gibberellin inhibitor, which reduces twig and leaf growth. The lack of growth regulation may be due to using the label rate, primarily intended for use on utility pruned trees with reduced crowns, and may be inadequate for large trees with fully developed crowns. The only significant increase measured was in twig growth in the year of the second application of nitrogen (Table 1). Growth regulation from PBZ treatment was not counteracting growth stimulation from nitrogen, since PBZ alone did not reduce twig growth.

The high nitrogen rate consistently increased SPAD in bur oaks fertilized at the high rate beginning the second year of application. The low nitrogen rate increased SPAD only after the last

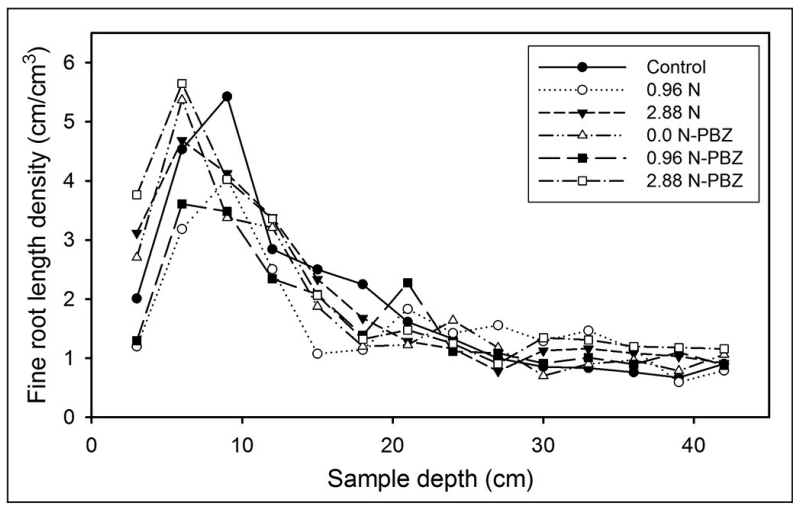

Figure 1. Broadcast slow-release nitrogen application at standard rates (ANSI 2011) and PBZ at label rate had no effect on fine-root development of mature bur oaks. There were no significant differences at any sampling depth. application. There was no increase in any year in white oak. There was no difference when PBZ was applied, though generally all PBZ treatments were generally somewhat higher than control (Table 2). Though PBZ is known to make leaves greener, there was no increase in SPAD from PBZ with or without nitrogen. There were no differences in leaf area or leaf nitrogen content for any treatment in both species (data not shown).

\section{Young Tree Experiment}

There was no whole root system response to granular broadcast or subsurface liquid injection fertilizer applications (Table 3). Concentrating the fertilizer in a portion of the root system by liquid injection did not produce a significant increase in fine-root development locally near the injection site (Table 4), as had been previously reported on a site just a few hundred meters away (Watson 1994). The use of a slow-release formulation in this study, versus a quick-release formulation and presumably higher concentrations of nutrients in the soil around the application site in the earlier study, may be responsible for the difference in response. The species used were different as well.

Fertilizer treatment did not affect average dbh increase after two years of nitrogen application (data not shown). The low fertilizer rate liquid injection treatment resulted in a significant increase in maple twig growth following the second nitrogen application only (Table 5). This isolated increase at the lower rate cannot be easily explained. Overall, twig growth was much lower the second season. This reduction in growth cannot be explained by weather or drought stress, since rainfall was near normal and temperatures somewhat below normal (data from

Table 1. Average twig growth after four consecutive years of slow-release N application and PBZ application in Year 1.

\begin{tabular}{|c|c|c|c|c|c|c|}
\hline \multirow[t]{2}{*}{ Species } & \multirow{2}{*}{$\begin{array}{l}\text { Nitrogen } \\
\text { rate }\left(\mathrm{kg} \mathrm{N} / 100 \mathrm{~m}^{2}\right)\end{array}$} & \multirow{2}{*}{$\begin{array}{l}\text { PBZ } \\
\text { (g a.i./cm dbh) }\end{array}$} & \multicolumn{4}{|c|}{ Average twig growth $(\mathrm{cm})$ after each annual $\mathrm{N}$ application } \\
\hline & & & Year 1 & Year 2 & Year 3 & Year 4 \\
\hline \multirow[t]{3}{*}{ Bur oak } & 0 & 0 & 6.2 & $6.8 a^{z}$ & 9.3 & 8.2 \\
\hline & 0.96 & 0 & 8.4 & $11.9 \mathrm{~b}$ & 9.4 & 7.9 \\
\hline & 2.88 & 0 & 7.2 & $8.8 \mathrm{~b}$ & 10.9 & 10.5 \\
\hline \multirow[t]{3}{*}{ Bur oak } & 0 & 1.2 & 9.5 & 7.9 & 8.4 & 6.8 \\
\hline & 0.96 & 1.2 & 5.9 & 8.9 & 10.3 & 7.2 \\
\hline & 2.88 & 1.2 & 9.3 & 8.9 & 9.1 & 10.0 \\
\hline \multirow[t]{3}{*}{ White oak } & 0 & 0 & 9.2 & 10.4 & 12.6 & 13.7 \\
\hline & 0.96 & 0 & 7.7 & 13.4 & 13.4 & 10.4 \\
\hline & 2.88 & 0 & 7.8 & 9.9 & 10.5 & 10.5 \\
\hline
\end{tabular}

${ }^{z}$ Values in the same column for the same species and treatment combination followed by different letters were significantly different at $P \leq 0.05$. 
Table 2. Relative chlorophyll content (SPAD) after PBZ application in Year 1 and 4 in consecutive years of slow-release $\mathrm{N}$ application.

\begin{tabular}{|c|c|c|c|c|c|c|}
\hline \multirow[t]{2}{*}{ Species } & \multirow[t]{2}{*}{$\begin{array}{l}\text { Nitrogen } \\
\text { rate }(\mathrm{kg} \mathrm{N} / 100 \mathrm{~m} 2)\end{array}$} & \multirow[t]{2}{*}{$\begin{array}{l}\text { PBZ } \\
\text { (g a.i./cm dbh) }\end{array}$} & \multicolumn{4}{|c|}{ SPAD after each annual $\mathrm{N}$ application } \\
\hline & & & Year 1 & Year 2 & Year 3 & Year 4 \\
\hline \multirow[t]{3}{*}{ Bur oak } & 0 & 0 & $42.36 \mathrm{a}^{\mathrm{z}}$ & $40.42 \mathrm{a}$ & $41.75 \mathrm{a}$ & $42.23 \mathrm{a}$ \\
\hline & 0.96 & 0 & $44.83 a$ & $45.28 \mathrm{ab}$ & $45.51 \mathrm{ab}$ & $47.08 \mathrm{~b}$ \\
\hline & 2.88 & 0 & $46.68 \mathrm{a}$ & $46.92 \mathrm{~b}$ & $47.93 \mathrm{~b}$ & $48.05 b$ \\
\hline \multirow[t]{3}{*}{ Bur oak } & 0 & 1.2 & 45.82 & 51.96 & 46.65 & 44.57 \\
\hline & 0.96 & 1.2 & 46.33 & 45.54 & 45.81 & 41.57 \\
\hline & 2.88 & 1.2 & 45.42 & 44.61 & 46.18 & 47.06 \\
\hline \multirow[t]{3}{*}{ White oak } & 0 & 0 & 40.34 & 39.78 & 39.44 & 39.98 \\
\hline & 0.96 & 0 & 41.12 & 42.60 & 42.93 & 42.01 \\
\hline & 2.88 & 0 & 41.31 & 40.56 & 42.80 & 41.74 \\
\hline
\end{tabular}

${ }^{\mathrm{z}}$ Values in the same column for the same species and treatment combination followed by different letters were significantly different at $P \leq 0.05$.

Table 3. Whole-tree fine-root density response to granular broadcast and subsurface liquid injection nitrogen fertilizer treatments. There were no significant differences between treatments.

\begin{tabular}{llll}
\hline Species & $\begin{array}{l}\text { Application } \\
\text { method }\end{array}$ & $\begin{array}{l}\text { Nitrogen rate } \\
\left(\mathrm{kg} \mathrm{N} / 100 \mathrm{~m}^{2}\right)\end{array}$ & $\begin{array}{l}\text { Avg. len/vol } \\
\left(\mathrm{cm} / \mathrm{cm}^{3}\right)\end{array}$ \\
\hline Black maple & Liquid injection & 0 & 1.96 \\
& & 0.96 & 2.42 \\
& & 2.88 & 3.08 \\
Green ash & Broadcast & 0 & \\
& & 0.96 & 1.44 \\
& & 2.88 & 1.45 \\
Green ash & Liquid injection & 0 & 1.28 \\
& & 0.96 & 2.00 \\
& & 2.88 & 2.11 \\
& & & 1.70 \\
\hline
\end{tabular}

Table 4. Fine-root density response to subsurface liquid injection nitrogen fertilizer treatments. There were no significant differences between treatments.

\begin{tabular}{llll}
\hline Species & $\begin{array}{l}\text { Fertilizer rate } \\
\left(\mathrm{kg} \mathrm{N} / 100 \mathrm{~m}^{2}\right)\end{array}$ & $\begin{array}{l}\text { Sampling } \\
\text { distance }(\mathrm{m})\end{array}$ & $\begin{array}{l}\text { Avg. len/Vol } \\
\left(\mathrm{cm} / \mathrm{cm}^{3}\right)\end{array}$ \\
\hline Black maple & 0 & 0.6 & 2.15 \\
& 0 & 1.2 & 1.79 \\
& 0 & 1.8 & 1.94 \\
& 0.96 & 0.6 & 2.90 \\
& 0.96 & 1.2 & 2.18 \\
& 0.96 & 1.8 & 2.19 \\
& 2.88 & 0.6 & 3.52 \\
Green ash & 2.88 & 1.2 & 3.56 \\
& 2.88 & 1.8 & 2.15 \\
& 0 & & \\
& 0 & 0.6 & 2.17 \\
& 0 & 1.2 & 1.81 \\
& 0.96 & 1.8 & 2.03 \\
& 0.96 & 0.6 & 1.51 \\
& 0.96 & 1.2 & 3.28 \\
& 2.88 & 1.8 & 1.54 \\
& 2.88 & 0.6 & 1.42 \\
& 2.88 & 1.2 & 2.29 \\
& & 1.8 & 1.40 \\
\hline
\end{tabular}

the NOAA weather station located at The Morton Arboretum). An unexplained smaller season-toseason decrease in growth in the maple low fertilizer rate treatment resulted in the significant difference and is not likely to be horticulturally significant.

Leaf area of ash was increased by both rates of liquid injection and the high rate of broadcast application after the first application (Table 5). This treatment effect did not reoccur after the second $\mathrm{N}$ application. Similar to twig growth, leaves were smaller the season after the second application. This overall reduced growth decreased the differences between treatment means and may itself have eliminated significant difference. No other explanation can be offered. There was no fertilizer treatment effect on maple leaf area in either year.

Fertilized ash and maple had higher relative chlorophyll content (SPAD) than controls after the first nitrogen treatment (one exception was ash, broadcast application, low rate). After the second fertilization, only the high rate broadcast treatment in ash was significantly higher (Table 5). The lack of differences in the second year was the result of the unfertilized controls being higher, since those values increased more over the previous year than the fertilizer treatments. The increase in controls compared to the year before cannot be explained. The measurements were taken earlier in the season, before the trees were harvested in the second year, but SPAD values have been shown to be lower earlier in the season, not higher (Neilsen et al. 1995)

In these studies, neither broadcast or liquid injection applications of slow-release nitrogen fertilizer at the lower and upper limits of the $A 300$ 
Table 5. Twig growth $(\mathrm{cm})$, leaf area $\left(\mathrm{cm}^{2}\right)$, and relative chlorophyll rating (SPAD) after two years of $\mathrm{N}$ fertilizer application.

\begin{tabular}{|c|c|c|c|c|c|c|c|c|}
\hline \multirow[t]{2}{*}{ Species } & \multirow{2}{*}{$\begin{array}{l}\text { Application } \\
\text { method }\end{array}$} & \multirow{2}{*}{$\begin{array}{l}\text { Nitrogen rate } \\
\left(\mathrm{kg} \mathrm{N} / 100 \mathrm{~m}^{2}\right)\end{array}$} & \multicolumn{2}{|c|}{ Twig growth $(\mathrm{cm})$} & \multicolumn{2}{|c|}{ Leaf area $\left(\mathrm{cm}^{2}\right)$} & \multicolumn{2}{|l|}{ SPAD } \\
\hline & & & Year 1 & Year 2 & Year 1 & Year 2 & Year 1 & Year 2 \\
\hline \multirow[t]{3}{*}{ Green ash } & \multirow[t]{3}{*}{ Liquid injection } & 0 & 7.8 & 3.9 & $73.2 a^{z}$ & 69.0 & $29.0 \mathrm{a}$ & 44.0 \\
\hline & & 0.96 & 9.7 & 7.7 & $87.5 b$ & 66.5 & $36.5 b$ & 43.9 \\
\hline & & 2.88 & 11.8 & 3.8 & $89.2 \mathrm{~b}$ & 60.7 & $38.2 b$ & 43.7 \\
\hline \multirow[t]{3}{*}{ Green ash } & \multirow[t]{3}{*}{ Broadcast } & 0 & 8.1 & 5.2 & $93.5 \mathrm{a}$ & 77.2 & $31.6 \mathrm{a}$ & $39.4 \mathrm{a}$ \\
\hline & & 0.96 & 7.7 & 4.0 & $99.2 \mathrm{a}$ & 76.9 & $33.6 \mathrm{ab}$ & $42.0 \mathrm{ab}$ \\
\hline & & 2.88 & 11.5 & 5.6 & $96.1 b$ & 71.0 & $45.4 \mathrm{~b}$ & $44.5 b$ \\
\hline \multirow[t]{3}{*}{ Black maple } & \multirow[t]{3}{*}{ Liquid injection } & 01 & 20.7 & $4.3 \mathrm{a}$ & 10.7 & 70.0 & $28.8 \mathrm{a}$ & 40.5 \\
\hline & & 0.96 & 34.4 & $12.8 \mathrm{~b}$ & 12.0 & 90.6 & $34.4 \mathrm{~b}$ & 34.9 \\
\hline & & 2.88 & 35.1 & $5.2 \mathrm{a}$ & 12.3 & 89.9 & $33.9 b$ & 35.1 \\
\hline
\end{tabular}

${ }^{z}$ Values in the same column for the same species and treatment combination followed by different letters were significantly different at $P \leq 0.05$.

Standard-recommended range, nor PBZ with or without fertilization, increased fine-root development or substantially affected crown growth of mature oak trees, or of young ash and maple trees.

The available sites with established trees on them were of reasonable soil quality with an undisturbed profile, which is not true of many urban sites. Since the soils were undisturbed with root systems established in them, fine-root density may have already been maximized for existing soil conditions, limiting increases from fertilizer and PBZ applications. In a situation where root development has been diminished by physical or environmental disturbances, the opportunity for fine-root increases from fertilizer and growth regulator treatments could be greater, especially if accompanied by cultural measures to improve the soil.

The study sites possessed moderate natural fertility. Supplemental fertilizers were not applied to the lawn grass surrounding the trees, which can also be available to the trees, but fallen leaves and grass clippings were not removed, adding to the natural fertility. Total soil nitrogen in the upper $15 \mathrm{~cm}$ of soil before application of nitrogen fertilizer was $0.21 \%$ on the oak site and $0.22 \%$ on the ash-maple site. These values are in the middle of the normal range of $0.06 \%-0.50 \%$ (Bremner 1965). Soil nitrogen availability was not likely to be limiting prior to the application of nitrogen fertilizer, and this may have limited tree response to the fertilizer treatments.

An earlier study on the same site as the younger tree experiment in this work did show a localized increase in fine-root development of other tree species (Watson 1994). In the earlier study, nitrogen was applied by filling drilled holes with quickrelease granular formulation, a practice that was more common in arboriculture at the time. The amount of $\mathrm{N}$ released into the soil around the application holes may have been higher could explain the greater root response in the earlier study.

There was no fine-root response of the oak trees to PBZ with or without N. Root response of mature oaks to PBZ basal drench applications was mixed across previous studies. Factors such as tree health and site quality may play a role in whether root development is increased by PBZ application.

PBZ treatment did result in a significant increase in fine-root density on chlorotic pin oak (Quercus palustris) trees compared to untreated chlorotic controls, but not on treated trees with normal foliage color compared to untreated trees with normal color (Watson and Himelick 2004). Fine-root density of the healthy green trees, in that study, as well as the current one, may have already been adequate, with little room for improvement.

Soil conditions may limit root response as well. There was no improvement of fine-root density on white oak in soil with minimal history of disturbance and long-established mulch on the surface (Watson 2006b). Fine-root density of pin oaks was increased in the topsoil after PBZ treatment, but not in clayey subsoils (Watson 1996). Root density of chlorotic pin oak trees was improved by PBZ treatment in minimally disturbed golf course soils, but not along streets where the surface soils are highly disturbed and possess high clay content resulting from land development processes that may have limited root development (Watson and Himelick 2004).

Though the nitrogen or PBZ applications did not achieve the desired effect of increasing fine root growth, or show substantial positive effect in the tree crowns, there were no negative effects either. The highest rate allowed by the fertilization standard (ANSI 2011) applied for five con- 
secutive years had no ill effects, even on mature aging oak trees. That being said, such a high rate still may not be wise given that it is up to 10 times greater than natural nutrient recycling in the forest, even without additional lawn fertilization. If the trees are not taking up the additional nitrogen, then it may be leaching through the soil and into the surrounding environment, which is a concern.

Fertilization of urban landscape trees may be appropriate in certain situations, but fertilization practices should be based on the condition and age of the tree, deficiency symptoms, nutrient analysis, and site conditions (ANSI 2011; Smiley et al. 2013). This work adds to the support for fertilization practices based on assessment of the tree and site conditions to avoid ineffective and unnecessary fertilization.

Acknowledgments. This study was funded, in part, by grants from The Care of Trees, Wheeling, Illinois and Rainbow Treecare Scientific Advancements, Minnetonka, Minnesota, U.S.

\section{LITERATURE CITED}

American National Standard Institute. 2011. American National Standard for Tree Care Operations - Tree, Shrub, and Other Woody Plant Management - Standard Practices (Soil Management a. Modification, b. Fertilization, and c. Drainage) (ANSI A300, Part 2). Tree Care Industry Association, Inc., Londonderry, New Hampshire, U.S.

Association of Official Analytical Chemists. 2012. Official methods of analysis of the AOAC International. nineteenth edition. In: George W. Latimer (Ed.). Association of Official Analytical Chemists. Gaithersburg, Maryland, U.S.

Barton, L., and T.D. Colmer. 2005. Irrigation and fertilizer strategies for minimizing nitrogen leaching from turfgrass. Agricultural Water Management 80:160-175.

Bigelow, C.A., J.J. Camberato, and A.J. Patton. 2013. Fertilizing established cool-season lawns: Maximizing turf health with environmentally responsible programs. <www.extension.purdue.edu/extmedia/ay/ay-22-w.pdf>

Bremner, J.M. 1965. Total nitrogen. pp. 1149-1178. In: C.A. Black (Ed.). Methods of Soil Analysis Part 2: Chemical and Microbiological Properties. The American Society of Agronomy, Inc., Madison, Wisconsin, U.S.

Chamuah, G.S. 1988. The effect of nitrogen on root growth and nutrient uptake of young tea plants (Camellia sinensis L.) grown in sand culture. Fertilizer Research 16:59-65.

Cregg, B., C. Rios, J. Hart, and D. Briggs. 2004. Fate of nitrates in field nursery production systems. USDA Forest Service Proceedings RMRS-P-33. pp. 50-54.

Cripps, R.W. 1992. N fertilization of field grown woody ornamentals. Proceeds of the SNA Research Conference 37:128-132.

Drew, M.C., and L.R. Saker. 1975. Nutrient supply and the growth of the seminal root system in barley II. Localized, compensatory increases in lateral root growth and rates of nitrate uptake when nitrate supply is restricted to only part of the root system. Journal of Experimental Botany 26:79-90.
Funk, R.C. 2000. The effect of fertilizer source and placement on tree growth. pp. 83-86. In: A. Siewert, B. Rao, and D. Marion (Eds.). Tree and Shrub Fertilization: Proceedings from an International Conference on Tree and Shrub Fertilization, 17-18 May 2000, Fairlawn, Ohio, U.S.

Gold, A.J., W.R. DeRagoon, W.M. Sullivan, and J.L. Lemunyon. 1990. Nitrate-nitrogen losses to groundwater from rural and suburban land uses. Journal of Soil and Water Conservation 45:305-310.

Green, T., and G.W. Watson. 1989. The effect of organic surface mulch on the establishment of bare root trees. Journal of Arboriculture 15:268-272.

Guillard, K., and K.L.Kopp. 2004. Nitrogen fertilizer form and associated nitrate leaching from cool-season lawn turf. Journal of Environmental Quality 33:1822-1827.

Hodge, A. 2004. The plastic plant: Root responses to heterogeneous supplies of nutrients. New Phytologist 162:9-24.

Ingram, D.L., B. Roach, and M. Klahr. 1998. Effects of controlledrelease fertilizers on growth and nutrient content of field-grown nursery crops. Proceeds of the SNA Research Conference 43:124-127.

Juntunen, M-L., and R. Rikala. 2001. Fertilization practice in Finnish forest nurseries from the standpoint of environmental impact. New Forests 21:141-158.

Landschoot, P. 2003. Turfgrass fertilization: A basic guide for professional turfgrass managers. <http://plantscience.psu.edu/ research/centers/turf/extension/factsheets/turfgrassfertilization-professional\# $\mathrm{ex}>$

Lanphear, L. 2000. Tree fertilization: An arborist's perspective. pp. 143-150. In: A. Siewert, B. Rao, and D. Marion (Eds.). Tree and Shrub Fertilization: Proceedings from an International Conference on Tree and Shrub Fertilization, 17-18 May 2000, Fairlawn, Ohio, U.S.

Larcher W. 1975. Physiological Plant Ecology. Springer-Verlag, Berlin and New York.

Mackie-Dawson, L.A., P. Millard, and M.F. Proe. 1995. The effect of nitrogen supply on root growth and development in sycamore and Sitka spruce trees. Forestry 68:107-114.

Mangiafico, S.S., and K. Guillard. 2007. Nitrate leaching from Kentucky bluegrass soil columns predicted with anion exchange membranes. Soil Science Society of America Journal 71:219-224.

National Resource Conservation Service. 2016. Web Soil Survey. $<$ http://websoilsurvey.nrcs.usda.gov/app/WebSoilSurvey.aspx >

Neely, D., E.B. Himelick, and W.R. Crowley, Jr. 1970. Fertilization of established trees: A report of field studies. Illinois Natural History Survey Bulletin 30(4):235-266.

Neilsen, D., E.J. Hogue, G.H. Neilsen, and P. Parchomchuk. 1995. Using SPAD-502 values to assess the nitrogen status of apple trees. HortScience 30:508-512.

Osmond, D.L., and D.H. Hardy. 2004. Characterization of turf practices in five North Carolina Communities. Journal of Environmental Quality 33:565-575.

Paré, K., M.H. Chantigny, K. Carey, W.J. Johnston, and J. Dionne. 2006. Nitrogen uptake and leaching under annual bluegrass ecotypes and bentgrass species: A lysimeter experiment. Crop Science 46:847-853.

Petrovic, A.M. 1990. The fate of nitrogenous fertilizer applied to turfgrass. Journal of Environmental Quality 19:11-14. 
Philipson, J.J., and M.P. Coutts. 1977. The influence of mineral nutrition on the root development of trees II. The effect of specific nutrient elements on the growth of individual roots of Sitka spruce. Journal of Experimental Botany 28:864-871.

Qu, L., A.M. Quoreshi, and T. Koike. 2003. Root growth characteristics, biomass, and nutrient dynamics of seedlings of two larch species raised under different fertilization regimes. Plant and Soil 255:293-302.

Robinson, D. 1994. The responses of plants to non-uniform supplies of nutrients. New Phytologist 127:635-674.

Rytter, L., T. Ericsson, and R.M. Rytter. 2003. Effects of demanddriven fertilization on nutrient use, root:plant ratio and field performance of Betula pendula and Picea abies. Scandinavian Journal of Forest Research 18:401-415.

Sartain, J.B. 2015. General Recommendations for Fertilization of Turfgrasses on Florida Soils. <https://edis.ifas.ufl.edu/pdffiles/ LH/LH01400.pdf>

Smiley, E.T, S.J. Lilly, and L. Werner. 2013. Best Management Practices: Tree and Shrub Fertilization. International Society of Arboriculture, Champaign, Illinois, U.S.

Smith, E. 2000. Tree growth as influenced by fertilizer placement. pp. 79-82. In: A. Siewert, B. Rao, and D. Marion (Eds.). Tree and Shrub Fertilization: Proceedings from an International Conference on Tree and Shrub Fertilization, held 17-18 May 2000, Fairlawn, Ohio, U.S.

Watson, G.W. 1988. Organic surface mulch and grass competition influence root development. Journal of Arboriculture 14:200-203.

Watson, G.W. 1991. Attaining root:crown balance in landscape trees. Journal of Arboriculture 17:211-216.

Watson, G.W. 1994. Root growth response to fertilizers. Journal of Arboriculture 20:4-8.

Watson, G.W. 1996. Tree root system enhancement with paclobutrazol. Journal of Arboriculture 22:211-217.

Watson, G.W. 2004. Effect of transplanting and paclobutrazol on root growth of 'Green Column' black maple and 'Summit' green ash. Journal of Environmental Horticulture 22:209-212.

Watson, G.W. 2006a. Establishing a relationship between soil aeration and fine-root development of seven tree species using the steel-rod technique. Arboricultural Journal 29:161-172.

Watson, G.W. 2006b. The effect of paclobutrazol treatment on starch content and mycorrhizal colonization and fine-root density of white oaks. Journal of Arboriculture 32:114-117.

Watson, G.W., and E.B. Himelick. 2004. The effects of soil pH, root density, and tree growth regulator treatments on pin oak chlorosis. Journal of Arboriculture 30:172-177.

Watson, G.W., and P.D. Kelsey. 2006. The impact of soil compaction on soil aeration and fine-root density of Quercus palustris. Urban Forestry and Urban Greening 4:69-74.

Wells, C.A., D. Whigham, and H. Lieuth. 1972. Investigation of mineral nutrient cycling in an upland piedmont forest. J. Elisha Mitchell Science Society 88:66-78.

Werner, L.W. 2000. Nitrogen relations of ornamental trees in urban soils: A first look. Master's Thesis. University of WisconsinStevens Point, Stevens Point, WI 54481. 99pp.

Yeager, T.H., and R.D. Wright. 1981. Influence of nitrogen and phosphorus on shoot-root ratio of Ilex crenata Thunb. 'Helleri.' HortScience 16:564-565.
Gary Watson (corresponding author)

The Morton Arboretum

4100 Illinois Route 53

Lisle, Illinois 60532, U.S.

gwatson@mortonarb.org

Angela Hewitt

The Morton Arboretum

4100 Illinois Route 53

Lisle, Illinois 60532, U.S.

Résumé. Les pratiques visant à favoriser la croissance racinaire des arbres ont été recherchées en arboriculture depuis de nombreuses années, en particulier pour le traitement des arbres stressés ou en déclin. La fertilisation des arbres est une pratique courante en arboriculture. Quelques résultats de recherche ont démontré que la fertilisation azotée peut augmenter la densité de fines racines dans les zones localisées du sol où l'engrais a été appliqué, mais l'effet sur le système racinaire dans son ensemble n'a pas été examiné. La recherche a rapporté un effet stimulant sur les fines racines à la suite d'une application basale du régulateur de croissance paclobutrazol, mais les résultats n'ont pas été constants. Davantage d'informations sont nécessaires. Une formulation granulaire à libération lente d'azote a été répandue sur l'ensemble du système racinaire de chênes matures pendant quatre années consécutives, avec ou sans une application basale de paclobutrazol lors de la première année. De l'azote a également été appliqué sur des frênes verts plus jeunes et des érables noirs par épandage granulaire ou par injection liquide dans le sol pendant deux années consécutives. Il n'y a pas eu d'augmentation globale du développement de fines racines à la suite d'aucun de ces traitements et aucune augmentation localisée à la suite des injections liquides dans le sol. La croissance réactive des houppiers était minime. Les profils de sol n'ont pas été altérés avec une disponibilité moyenne d'azote naturel. Les résultats suggèrent que la fertilisation systématique des arbres, selon les doses habituellement recommandées, peut être inefficace si la fertilité du sol est modérée.

Zusammenfassung. Praktiken zur Unterstützung von Wurzelwachstum sind in der Arboristik seit vielen Jahren gefragt, besonders als eine Behandlung für Bäume, die gestresst sind oder eine verminderte Vitalität aufweisen. Baumdüngung ist eine häufige Praxis in der Arboristik. Einige wenige Forschungsberichte haben gezeigt, dass eine Stickstoffdüngung die Feinwurzeldichte in der Bodenregion, wo der Dünger appliziert wurde, vergrößerte, aber der Effekt auf das gesamte Wurzelsystem wurde noch nicht untersucht. Die Forschung berichtete über einen Feinwurzel stimulierenden Effekt nach einer basalen Applikation von dem Wachstumsregulator Paclobutrazol, aber die Ergebnisse waren nicht konstant. Es ist mehr Information erforderlich. Über einen Zeitraum von vier aufeinander folgenden Jahren wurde über das gesamte Wurzelsystem von ausgewachsenen Eichen ein sich langsam abbauender Stickstoffdünger in Granulatform aufgebracht, mit oder ohne einer Basalapplikation von Paclobutrazol im ersten Jahr. Über zwei Folgejahre wurde bei jungen Eschen und Ahornen auch entweder Stickstoff als Granulat oder als flüssige Bodeninjektion aufgebracht. Bei keiner der Behandlungen gab es einen allgemeinen Zuwachs von Feinwurzeln und bei der flüssigen Applikation gab es auch keinen lokalen Zuwachs. In der Krone war der Einfluss auf den Zuwachs nur minimal. Die Ergebnisse zeigen, dass eine Routine-Düngung von Bäumen mit einer standardmäßig empfohlenen Menge ineffektiv sein kann, wenn die Bodenfruchtbarkeit moderat ist. 